\title{
Eldina Lovaš
}

(Poslijediplomski studij povijesti / Interdisciplinarna doktorska škola, Sveučilište u Pečuhu)

\author{
OSJEČKO GRAĐANSTVO \\ U UPISNIKU GRAĐANA OD STJECANJA \\ SLOBODNOG I KRALJEVSKOG STATUSA \\ DO PRVOG POPISA NEPLEMENITOG \\ STANOVNIŠTVA (1809.-1814.)
}

UDK 314:94(497.5 Osijek)“1809/1814“

Izvorni znanstveni rad

Primljeno: 23. 1. 2019.

U radu se na temelju podataka evidentiranih u osječkom Upisniku građana analizira osječko građanstvo između 1809. i 1814. godine. U radu se daje kratak opis izvora koji omogućavaju istraživanje osječkih građana, navode se građanska prava koja su zajamčena Poveljom slobodnog i kraljevskog grada Osijeka iz 1809. godine te uvjeti primanja u građanstvo. Analiza podataka temelji se na Upisniku jer taj izvor donosi najviše pojedinačnih podataka o svakom građaninu. Primjenom statističke, komparativne i deskriptivne metode nastoji se prikazati broj, vjerska i „nacionalna“ struktura, bračni status i vrste djelatnosti osječkih građana. Rad obuhvaća razdoblje od 1809., kada je Osijek stekao slobodni i kraljevski status, do 1814. godine, kada je osječko neplemenito stanovništvo prvi put popisano. To je, dakle, prvi popis neplemenitih građana nakon što je Osijek proglašen slobodnim i kraljevskim gradom.

Ključne riječi: građanstvo, Upisnik građana, Osijek, slobodni i kraljevski grad, početak 19. stoljeća 


\section{Uvod}

Prošlo je više od dva stoljeća otkad je Osijek proglašen slobodnim i kraljevskim gradom. Novi pravni položaj sa svim privilegijama koje je grad stekao 1809. godine predmet je istraživanja sve do danas, a što dokazuje i mnoštvo objavljenih izvora ${ }^{1}$ iz toga razdoblja te monografije i znanstveni radovi koji se bave različitim aspektima (pravnim, političkim, upravnim, gospodarskim, kulturnim, demografskim i sl.) $)^{2}$ Osijeka kao slobodnog i kraljevskog grada. Zanimljivo je da je većina radova posvećena novom političko-pravnom položaju grada, uređenju i funkcioniranju gradske uprave, dok je najmanji istraživački interes iz toga razdoblja pokazan prema osječkom stanovništvu.

Unatoč tome što je osječko stanovništvo od 1809. godine redovito dokumentirano, a izvori dobro sačuvani, ${ }^{3}$ do sada je o toj temi napisano samo nekoliko radova. Većina njih temelji se na sumarnom popisu iz 1814. godine, ${ }^{4}$

${ }^{1}$ Nakon proglašenja Osijeka slobodnim i kraljevskim gradom najviše je izvora iz toga vremena
objavio Stjepan Sršan. Među njima su: Prvi zapisnik slobodnog i kraljevskog grada Osijeka
1809. godine, prir. i prev. Stjepan Sršan (Osijek, 2009); Zapisnik političkih i gospodarskih
odluka slobodnog i kraljevskog grada Osijeka za 1810. i 1811. godinu, prir. Stjepan Sršan
(Osijek, 2011); Političko-gospodarski zapisnici slobodnog i kraljevskog grada Osijeka od
3. siječnja do uključivo 31. prosinca 1812. godine, prir. i prev. Stjepan Sršan (Osijek, 2012).
Isti autor je u više izdanja objavio i prijevod Povelje slobodnog i kraljevskog grada Osijeka:
Stjepan Sršan, Slobodni i kraljevski grad Osijek 1809. (Osijek, 2009), 49-67. U istom je iz-
danju preveo i Prvi i drugi dodatak za primjenu Diplome, 69-82, a slično izdanje izašlo je i
u koautorstvu: Stjepan Sršan i Tihomir Stojčič, Libera regiaque civitas Essek 1809. (Osijek,
1989). Višejezičnu publikaciju Povelje objavio je i Muzej Slavonije: Diploma eliberationes
liberae regiaeque civitatis Essekiensis, ur. Ante Grubišić (Osijek, 2010).

${ }^{2}$ Iz toga područja objavljeno je mnoštvo radova. Većina njih bavi se političko-pravnim položajem Osijeka, organizacijom gradske uprave, osječkim gradonačelnicima, sudskim poslovima Poglavarstva, graditeljstvom grada od 1809. godine. Među autorima može se istaknuti Stjepan Sršan s nekoliko monografija o Osijeku. Za njegovo se ime veže i nekolicina znanstvenih radova. Osim njega nekoliko radova objavili su: Ive Mažuran, Stanislav Marijanović, Andrija Šuljak i Josip Adamček. Osijeku je posvećena i jedna cijela monografija Ive Mažurana pod naslovom Od turskog do suvremenog Osijeka (Osijek, 1996), kao i cijeli deseti broj Glasnika arhiva Slavonije i Baranje, izdan u Osijeku 2009. godine. Treba istaknuti i istraživačku djelatnost Josipa Bösendorfera, na primjer: Josip Bösendorfer, „Kako je Osijek postao kr. i sl. grad", Narodna starina Vol. 8., No 18 (1929), 33-40; Josip Bösendorfer, Kraljevska povelja kojom se Osijek povisuje na stepen slob. i kralj. grada (Osijek, 1910); Josip Bösendorfer, Crtice iz slavonske povijesti s osobitim obzirom na prošlost županija: Križevačke, Virovitičke, Požeške, Cisdravske, Baranjske, Vukovarske i Srijemske, te Kr. i slob. grada Osijeka u srednjem i novom vijeku (Osijek, 1910).

${ }^{3}$ O svim izvorima koji su vezani za slobodni i kraljevski grad Osijek izdan je sumarni inventar: Vesna Božić-Drljača i Danijel Jelaš, Poglavarstvo slobodnog i kraljevskog Osijeka 1809.1850. (Osijek, 2016).

${ }^{4} \mathrm{U}$ literaturi se taj popis često naziva i popisom iz 1815. godine. Pregledala sam sva tri sveska neplemenitog osječkog stanovništva i u njima nisam pronašla ni jednu osobu koja je rođena 1815. godine. Zbog toga smatram da je taj popis prikladnije nazvati po godini njegova pro- 
što je i razumljivo, jer je to prvi cjelovit popis koji je obuhvatio čitavo osječko neplemenito stanovništvo. ${ }^{5} \mathrm{Na}$ temelju tog popisa Ive Mažuran ${ }^{6}$ i Dubravka Božić Bogović ${ }^{7}$ donose zbirne podatke o stanovništvu osječkih gradskih četvrti prema različitim kriterijima: broju stanovnika, spolu, vjerskoj pripadnosti, društvenoj i dobnoj strukturi te bračnom stanju, dok Stjepan Sršan donosi sumarne podatke o broju kuća, kućanstvima i o vjerskoj strukturi muškoga stanovništva. ${ }^{8}$ Među povjesničarima je do sada najmanji istraživački interes pokazan prema osječkom građanstvu, iako su oni bili najprivilegiranija društvena skupina, tj. zahvaljujući svome statusu bili su jedini uživatelji građanskih prava. Njima je do sada posvećen jedan pregledni rad Stjepana Sršana koji se temelji na nabrajanju građanskih povlastica, opisivanju Knjige građa$n a^{9}$ kao izvora za istraživanje građanstva i na navođenju zanimanja građana između 1809. i 1847. godine. ${ }^{10}$ Stjepan Sršan je s njemačke gotice preveo i dnevnik osječkog građanina Sebastijana Karla Redelsteina. ${ }^{11}$

Slabiji interes prema istraživanju građanstva i gradskoga društva, ${ }^{12}$ između ostalog i onog osječkog, može se temeljiti na više čimbenika. Kako bi se istražilo cjelovito stanovništvo jednog grada, potrebni su cjeloviti i dobro

vođenja, nego po godini obrade njegovih podataka, što je bilo 1815. godine. Osim sumarnog popisa, sačuvani su i pojedinačni popisi za svaku gradsku četvrt.

${ }^{5}$ Popis koji je obuhvatio cijelo stanovništvo, osim neplemenitog stanovništva, a popisao je i plemiće i kler, bio je popis za vrijeme Josipa II. između 1784. i 1787. godine. O tome da su popisivači u njega upisali i pripadnike crkvenih redova najbolje svjedoči zapis Ljetopisa osječkih franjevaca iz 1784. godine: „Ove je godine započeo sveopći popis svjetovnjaka i redovnika. Na nj su morali osobno doći svi, zatim je svakoj kući dan kućni broj, a da se ne bi tko mogao sakriti, poslani su izaslanici iz kuće u kuću i to mjesni župnik s maticom, županijski sudac u svojem okrugu, mjesni bilježnik i vojni časnik s jednim podređenim vojnikom. Kod nas su bili 18. XI. te su samostan obilježili brojem 101." Stjepan Sršan, Osječki ljetopisi 1686.-1945. (Osijek, 1993), 105.

${ }^{6}$ Mažuran, Od turskog do suvremenog Osijeka, 91-98.

${ }^{7}$ Dubravka Božić Bogović, „Demografska slika Osijeka od 1809.“, Glasnik arhiva Slavonije i Baranje 10 (2009), 201-216.

${ }^{8}$ Stjepan Sršan, „Kako je Osijek 1809. godine postao slobodan i kraljevski grad“, Glasnik arhiva Slavonije i Baranje 10 (2009), 33.

${ }^{9}$ Izvor je abecedni Upisnik građana, samo ga Sršan naziva Knjigom građana.

${ }^{10}$ Stjepan Sršan, „Građanstvo slobodnog i kraljevskog grada Osijeka od 1809. do 1848. godine", Glasnik arhiva Slavonije i Baranje 10 (2009), 117-126.

${ }^{11}$ Stjepan Sršan, Osječki dnevnik Sebastijana Karla Redelsteina 1804.-1832. (Osijek, 1997).

${ }^{12}$ Istraživački interes prema gradovima i gradskom društvu pojavio se u drugoj polovici 19. stoljeća s pojavom velikih industrijskih gradova. Znanstveno istraživanje gradova prvi se put pojavilo u Engleskoj, a zatim u Americi. U pogledu metodološkog pristupa pojavilo se nekoliko definicija gradova: statistička, ekonomska, sociološka i funkcionalna. Vera Bácskai, „Várostörténet”, u: Bevezetés a társadalomtörténetbe, ur. Zsombor Bódy i József Ö. Kovács (Budapest, 2006), 245-259. 
sačuvani izvori. Kako su pojedini popisi, npr. popis poreznih obveznika, kućevlasnika ili neplemenitog stanovništva, ograničenog opsega, tj. ne popisuju stanovništvo u cjelini, već prema unaprijed određenom kriteriju popisuju određene ciljne skupine, potrebno je skupiti sve vrste izvora i temeljitom analizom pokušati rekonstruirati gradsko društvo u određenom vremenu. Druga je problematika što u njima često nedostaju oni koji samo djelomično plaćaju poreze ili oni koji ih uopće ne plaćaju, a i to što se takvi u većini slučajeva uvrštavaju u skupinu ,siromašnih“. Problem gradskih popisa jest to što do 1848. godine poznaju samo feudalno društveno uređenje i prema njihovim rubrikama stječe se dojam o statičnosti društva, što je, naravno, netočno. ${ }^{13}$ Problem s kojim se istraživači mogu susresti jest i pitanje jesu li zaista sve ciljne skupine popisane, a ako jesu, jesu li uvrštene u prave kategorije, kako su se popisivači odnosili prema privremenoj radnoj snazi, tzv. „sezoncima“, koji su samo kratko boravili u gradovima kako bi svoju egzistenciju ili osigurali ili povećali.

Dakle, može se, prvenstveno zbog obilježja izvora, zaključiti da je gradsko stanovništvo najbolje istraživati na osnovi više mikrostudija, ciljajući na određene društvene skupine. Upravo je zbog toga predmet ovoga rada osječko građanstvo za čije istraživanje postoji više izvora. Istraživanje je osječkih građana višestruko zanimljivo. Kao prvo, zanimljivo je istražiti građane gradova koji su relativno kasno stekli status slobodnog i kraljevskog grada. Toj skupini pripada i Osijek, koji se za svoj novi pravni status izborio tek 1809. godine. Naime, dok su građani drugih kraljevskih gradova, zahvaljujući gospodarskim promjenama, promijenjenom načinu života i bogaćenju u pravnom smislu negrađana, u praksi samo nominalno uživali svoja stara građanska prava i privilegije, osječkom je stanovništvu tek tada omogućeno njihovo stjecanje.

Primjenom statističke metode moguće je pratiti interes osječkih stanovnika prema sjecanju građanskog prava, tj. na godišnjoj razini prikazati broj novih građana. Građanstvo je, naime, moguće klasificirati prema vjerskoj pripadnosti, zanimanju, narodnosti i bračnom statusu te staležu kojima su pojedini građani pripadali. Komparativnom metodom moguće je usporediti zanimanje građana s njihovom narodnošću i vjerom. Zahvaljujući svim navedenim karakteristikama, moguće je utvrditi koliko je Osijek kao slobodan i kraljevski grad bio otvoren prema davanju građanskih prava strancima i je li magistrat to pravo više „čuvao“ za domaće stanovništvo ili su ga u jednakoj mjeri mogli uživati i stranci.

Rad je vremenski ograničen na razdoblje od 1809. godine, kada su se proglašenjem Osijeka slobodnim i kraljevskim gradom u feudalnom uređenju stvorili preduvjeti za stjecanje građanskog prava, a sve do 1814. godine, tj. do prvog popisa osječkog neplemenitog stanovništva. Razlog je tomu to što

${ }^{13}$ Vera Bácskai, Városok Magyarországon az iparosodás elött (Budapest, 2002), 123-124. 
je u prvim godinama nakon proglašenja Osijeka slobodnim i kraljevskim gradom godišnje evidentiran najveći broj građana, a i to što se od 1814. godine građani mogu pratiti i iz popisa osječkog neplemenitog stanovništva koji se može analizirati i primjenom druge metodologije, npr. one Petera Lasletta u rekonstrukciji kućanstva.

\section{Izvori za istraživanje osječkog građanstva}

Izvori za istraživanje osječkoga građanstva mogu se podijeliti u dvije skupine. U primarne izvore ubraja se tzv. Upisnik građana (Conotatio Individuorum in Libera et Regia Civitate Eszekiensi), ${ }^{14}$ koji donosi najviše pojedinačnih podataka o svakom građaninu, i tzv. Knjiga građana Slobodnog i kraljevskog grada Osijeka, koja je kasnije služila i kao Knjiga začasnih građana,${ }^{15}$ te koja u svojim rubrikama, u odnosu na prethodni izvor, donosi manje pojedinačnih podataka. U sekundarne izvore mogu se ubrojiti Zapisnici političkih i gospodarskih odluka slobodnog $i$ kraljevskog grada Osijeka, svi predmeti gradskoga magistrata koji su na bilo koji način povezani s građanima (prihodi, molbe za primanje u red građana, žalbe, tužbe i sl.) te oporuke koje, osim imovinsko-pravnih odnosa, donose podatke i o svakodnevici osječkih građana, o njihovim obiteljima, odnosima unutar obitelji, materijalnim predmetima i tako dalje. ${ }^{16}$

Osječki je Upisnik građana ${ }^{17}$ tvrdog uveza. Korice su ornamentirane: na tirkizno plavoj pozadini nalaze se svijetlo smeđi otisci motiva cvijeća i listova. Upisnik ima oblik knjige i može se zavezati. Gotovo je u cijelosti pisan latinskim jezikom i kurzivnom humanistikom. Izuzetak su samo pojedine godine, npr. 1821., 1822. i 1838. godina, kada su zanimanja pojedinih građana upisana njemačkom goticom. Izvor je dobro sačuvan, osim korice, nije oštećen. Zapisi su uredni do 1837. godine, a nakon toga postaju sve neuredniji. Iz rukopisa se vidi da su knjigu vodile dvije osobe, prva osoba od 1809. do 1814. godine, a druga od 1815. do 1848 . godine. ${ }^{18}$ Zapisi nisu oštećeni, u njima je malo križanja i ispravaka, nema tragova oštećenja, izlijevanja tinte i slično. Stranice izvora nisu numerirane. Pretraživanje je izvora olakšano jer su na desnoj strani istaknuta slova abecede po kojima se mogu pretraživati pojedine osobe. Izvor započinje sadržajem okružnice pod brojem 14868 od 3. i 25. rujna 1799.

${ }^{14}$ HR-DAOS-6.1.6, knj. 460.

${ }^{15}$ HR-DAOS-10, knj. 1187.

${ }^{16}$ Kao što je već spomenuto, za istraživanje osječkog građanstva prikladni su i različiti popisi, ali oni ovdje nisu opisivani jer nisu predmet istraživanja.

${ }_{17}$ Opis izvora postoji i kod Sršana („Građanstvo“, 120-121).

${ }^{18}$ Stjepan Sršan u svom radu o osječkom građanstvu navodi da je knjigu vodila samo jedna osoba. 
godine, u kojoj su regulirane pristojbe za građanski status za pojedine skupine na području Habsburške Monarhije, a one su vrijedile i za Osijek. Prema toj okružnici, u slobodnim i kraljevskim gradovima sinovi građana trebali su uplatiti 4 forinte, obrtnici i trgovci koji su potjecali iz kraljevstva ili izvan njega 8 forinti, a plemići i odličnici 25 forinti pristojbe za građanski status. ${ }^{19}$

Upis građana može se pratiti od 1809. godine. Prvi je građanin koji je upisan Axmann, Michael, po zanimanju tesar, rimokatoličke vjeroispovijesti, Austrijanac, oženjen, a za građanski status platio je 8 forinti. Zadnji upis nastao je 1848. godine. ${ }^{20}$ Posljednji upisani građanin je Hrabal, Franz, rimokatolik, po zanimanju majstor, Osječanin, oženjen, i za svoj je status izdvojio 25 forinti. ${ }^{21}$ Građani su u Upisniku upisani abecednim redom i kronološkim slijedom. Kriterij su abecednog upisa prezimena, stoga se građani prvo upisuju prezimenom, a zatim imenom. Kronološki upis za svoj kriterij pak uzima godinu stupanja u gradsku svezu. Između 1809. i 1848. godine upisano je ukupno 992 građana, a od kojih je 569 (57,39\%) steklo građanski status između 1809. i 1814. godine.

Do 1813. godine postoji redovita numeracija ispred prezimena građana, ali ta praksa od 1814. godine polako nestaje. Građani su u knjigu upisani po stupcima. Prvi se stupac odnosio na redni broj građana ( $N$. Serialis), drugi na ime i prezime (Nomen et Cognomen), treći na vjeru (Religio), četvrti na obrt ili drugo zanimanje/status (Opificium aut Subsistentia Status), zatim slijedi narodnost (Natio), bračni status: samac ili oženjen (Caelebs aut Uxoratus), ulaganje u obveznicama (Solvis in Schaedis Bancalibus) i u posljednjem stupcu visina uplaćene pristojbe u forintama (Titulo Taxe Concivitatis). Pojedine napomene upisivale su se na kraj retka. U Političko-gospodarskom zapisniku iz 1812. godine navodi se da se od gradskoga magistrata traži vođenje popisa građana koji bi se poslije koristio i za izbore: „a glede popisa građana (...) da se dadne prema prijedlogu s naznakom svojstva, vjeroispovijesti, narodnosti i stanja svakog građanina, kako bi se mogao služiti za izbore“, 22 a kako abecedni Upisnik počinje rečenicom: „Conotatio Individuorum in Libera et Regia Civitate Eszekiensi a tempore eius Installationis 28 utpote Aug. 1809. usque ultimam 8bris 1812 in Concivilitatem assumptorum", ${ }^{23}$ može se pretpostaviti da se Upisnik počeo redovito voditi tek od 1812. godine.

${ }^{19}$ Tekst na latinskom glasi: „Virtue Relationis Regio. d.d. 3. 7bris 1799. Emonatae et sub 25. 7bris 1799. N. 14868 circulariter intimate taxam Concivilitatis pro Gremialibus Civium filiis in 4ft, pro Opificibus et Mercatores intra et extra Regnaus in $8 \mathrm{ft}$ pro Nobilibus et Districtionibus in 25ft defixam." HR-DAOS-6.1.6, knj. 460.

${ }^{20}$ Stjepan Sršan u svom radu kao posljednju godinu upisa navodi 1847. godinu.

${ }^{21}$ HR-DAOS-6.1.6, knj. 460.

${ }^{22}$ Političko-gospodarski zapisnici, 345.

${ }^{23}$ HR-DAOS-6.1.6, knj. 460. 
Drugi primarni izvor koji sadržava detaljne podatke o osječkim građanima jest Knjiga začasnih građana. Izvor je tvrdog uveza, rubovi su ornamentirani zlatnim geometrijskim likovima, hrbat je u zlatotisku, listovi su knjige pozlaćeni. Prve dvije stranice izrađene su tehnikom kaširanja. Stranice su numerirane te je na svakoj označena jedna okvirna stranica unutar koje su se unosila imena građana. Izvor ukupno ima 47 stranica. Za razliku od Upisnika građana, u Knjigu začasnih građana upisivala su se samo četiri podatka: redni broj upisa (Nrus Serialis), datum stjecanja građanskog statusa (Datum depositi Iuramenti), ime i prezime građanina (Nomen \& Cognomen) i njegov status, tj. zanimanje (Conditio). U tu su se knjigu građani upisivali prema datumu stjecanja građanskog statusa. Prvi se upis odnosi na Joannesa Baranyaya koji je građaninom postao 6. listopada 1809. godine, imao je status plemića (nobilis) i bio je gradski sudac (iudex cittis). Njega su pratili ostali članovi gradskoga magistrata. Posljednji se upis odnosi na začasnog građanina Nikolu Živanovića, bivšeg osječkog gradonačelnika, koji je svoj status stekao 13. 11. 1883. godine. ${ }^{24}$ Između 1809. i 1883. godine upisano je ukupno 1125 osoba. Od tih se upisa 523 odnose na promatrano razdoblje. Na kraju izvora nalazi se abecedno kazalo prema prezimenima građana. Pokraj svakog prezimena stoji broj stranice i redni broj upisa, prema kojemu se osobe mogu pretraživati. U Knjigu su se od 1830. godine počeli upisivati i začasni građani.

Upisnik građana i Knjiga začasnih građana se razlikuju. Razlika nije samo u formalnim kriterijima upisivanja, već je ona kvantitativne prirode, tj. uočava se u broju građana koji su upisani u promatranom razdoblju - u Upisnik građana upisano je 46 osoba više u odnosu na Knjigu začasnih građana. Osim toga, u pojedinih osoba uočavaju se razlike u godini stupanja u gradsku svezu; npr. Zanetti, Joannes u Upisniku je upisan kod 1811. godine, dok drugi izvor navodi da je građanski status stekao godinu dana ranije, tj. 8 . lipnja 1810. godine. ${ }^{25}$ Isto tako, u pojedinih osoba razlikuju se i zanimanja: Markovics, Mathias koji je građanski status stekao 1810. godine u Upisniku se pojavljuje kao obućar, dok je u Knjizi začasnih građana upisan kao kožar. ${ }^{26}$ Kako Upisnik građana donosi više pojedinačnih podataka o svakom građani$\mathrm{nu}$, analiza podataka temeljit će se na njemu.

Treći izvor koji je pogodan za proučavanje osječkih građana jesu Političko-gospodarski zapisnici Slobodnog i kraljevskog grada Osijeka, u kojima se

${ }^{24}$ HR-DAOS-10, knj. 1187.

${ }^{25}$ Slični se problemi pojavljuju, primjerice, kod: Vintera, Michaela: 1813; 28. 12. 1812., Uxarecicsa, Josephusa: 1813; 28. 12. 1812., Srimcsevicha, Michaela: 1813; 28. 11. 1812., Seidla, Joannesa: 1813; 28. 12. 1812., baruna Prandaua, Josephusa: 1814; 29. 12. 1815., Penjiha, Philippusa: 1813; 28. 12. 1812., Poplera, Leopoldusa: 1813; 28. 12. 1812., Puczenicha, Mathiasa: 1811 ; 8. 1. 1809. i drugih.

${ }^{26}$ HR-DAOS-6.1.6, knj. 460; HR-DAOS-10, knj. 1187. 
mogu pronaći zabilježeni razni predmeti vezani za osječko građanstvo. Među njima mogu se pronaći molbe pojedinaca za stjecanje građanskog statusa. Tako je molba gradskog odvjetnika Sebastijana Papphazyja odobrena 1809. godine, ${ }^{27}$ no nisu sve molbe bile prihvaćene. U većini slučajeva za takve je osobe upisano da su „molitelji dijelom Zastupstvu nepoznati, a dijelom bez dovoljno iskazanih zasluga te se trebaju strpjeti“" ${ }^{28}$ što je značilo da su nakon nekog vremena ponovno mogle poslati molbu. Godine 1812. odbijena je molba Ivanu Baliću jer je dokumentacijom trebao potkrijepiti karakter svoje trgovačke djelatnosti, Jakobu Janiću zbog „,neprimjerenog načina života“, a Šimunu Petlovcu zbog duga u iznosu od 17 bečkih forinti. ${ }^{29}$

Iz zapisa se može doznati da su pojedinci koji zbog bolesti nisu mogli doći na polaganje prisega mogli prisegnuti i kod kuće. Takav je i slučaj Matije Vagnera, koji se 1809. pozvao na narušeno zdravlje rekavši kako „ne može doći u vijećnicu na sjednicu da položi prisegu sugrađanstva te moli da se pošalju dva gospodina poglavarstvenika zbog njezinog polaganja“.${ }^{30}$ Molba mu je odobrena te su ga 25. listopada u popodnevnim satima posjetili satnik Aleksandar Čavrak i tajnik Petar Bogoević kako bi prisegnuo. ${ }^{31}$

Također, iz zapisa se doznaje da su članovi magistrata stekli građanski status bez plaćanja uobičajene pristojbe, pravdajući tu odluku kao „znak i priznanje podnesenih napora u poslovima ovoga grada". ${ }^{32}$ Iz navedenoga se može zaključiti da zapisi mogu poslužiti i za daljnje istraživačke teme vezane za osječko građanstvo.

\section{Građanska prava i uvjeti primanja u građanstvo}

Jedan od osnovnih preduvjeta za stjecanje građanskog statusa bilo je stanovanje ili doseljenje na područje koje je imalo status slobodnog i kraljevskog grada. Ta je praksa bila u primjeni još od srednjega vijeka, tj. od pojave prvih slobodnih i kraljevskih gradova, a opstat će sve do formalnog ukidanja feudalizma 1848. godine.

Put Osijeka k samostalnosti bio je dug i težak. Prvi pokušaji ujedinjenja gradskih četvrti javljaju se za vrijeme vladavine Marije Terezije, 1746. godine. Naime, godinu dana ranije Engelshofen-Patačićeva komisija razgraničila

\footnotetext{
${ }^{27}$ Prvi zapisnik, 461.

${ }^{28}$ Političko-gospodarski zapisnik, 80.

${ }^{29}$ Isto, 167.

${ }^{30}$ Prvi zapisnik, 227.

${ }^{31}$ Isto, 277.

${ }^{32}$ Isto, 221
} 
je Slavoniju na civilni i vojni dio. Osijek je tim razgraničenjem postao dijelom civilnog područja u sklopu Virovitičke županije. Kako je grad bio najjače i najrazvijenije središte županije, Engelshofen ga je htio učiniti županijskim središtem. No, preduvjet za takvu funkciju bilo je ujedinjenje osječkih gradskih četvrti. Zbog toga je Marija Terezija od županije zatražila izradu prijedloga za njihovo ujedinjenje. U čitavom procesu nije se moglo zanemariti ni mišljenje triju osječkih općina pa je preko Ugarske dvorske komore, njihovog feudalnog gospodara, o tome zatraženo njihovo očitovanje. Pozvavši se na svoja pojedinačna prava (održavanje sajmova, lokalna samouprava, ubiranje raznih nameta i sl.), općine su na koncu donijele zaključak da njihovo ujedinjenje nije nužno pa zbog toga nije ni provedeno. ${ }^{33}$

Drugi razgovor o ujedinjenju započeo je 1780. godine, kada su se sastali suci triju osječkih samostalnih komorskih općina kako bi se dogovorili o uvjetima ujedinjenja. Toj se zamisli o ujedinjenju suprotstavio samo Gornji grad, ali je na kraju pristao na uvjete jer se počelo postavljati pitanje je li gradskim općinama bolje ujediniti se $u$ jedan magistrat i tako zajednički raspolagati dobitcima i izdatcima ili će namete i dalje svi plaćati pojedinačno. Naime, Osijek je u 18. stoljeću postao važno gospodarsko i trgovačko središte pa se oslobođenjem od plaćanja velikih feudalnih davanja mogao brže razvijati, a većina prihoda ostala bi u gradskoj blagajni. Do ujedinjenja je došlo 1786. godine, za vrijeme vladavine Josipa II. ${ }^{34}$ Kako je uvjet teritorijalnog jedinstva zadovoljen, stekli su se preduvjeti i za oslobođenje od feudalne vlasti Ugarske dvorske komore. Pregovori su okončani 1809. godine, kada je Franjo I. izdao osloboditeljsku povelju te je Osijek postao slobodnim i kraljevskim gradom. ${ }^{35}$ U njoj su regulirani svi odnosi, prava i obveze grada i građana, a pravno gledano, Osijek je uvršten u četvrti plemićki red.

Proglašenjem Osijeka slobodnim i kraljevskim gradom osječki su građani stekli niz privilegija: u pogledu državnog statusa izjednačili su se s plemićima, oslobođeni su plaćanja tridesetine na svoju uvezenu ili izvezenu robu na područje kraljevstva ili Ugarske, poreza, carina i podvoza, imali su pravo krčmarenja, točenja pića na malo i mesarenja, pravo na ribolov i lov na divljač i ptice, pravo na podizanje ljekarni, dućana, kupališta, kazališta, plesališta i streljana. Građani se zbog tuđih dugova nisu mogli zatvarati niti im se mogla

${ }^{33}$ Sršan, Slobodni i kraljevski grad, 13-23.

${ }^{34}$ Isto, 27.

${ }^{35}$ U Povelji je nabrojeno nekoliko zasluga kojima Osijek može zahvaliti svoj novi status, a među njima su: briga za kraljevstvo, kralja i Habsburšku dinastiju, zasluge tijekom borbe protiv Osmanlija, pomoć koju su Osječani pružili tijekom Napoleonovih ratova, dobrovoljni novčani darovi, održavanje nasipa kod Bilja, lomljenje leda na Dravi, donošenje materijala za izgradnju brodova i sl. Sršan, Slobodni i kraljevski grad, 50-52. O Napoleonovim vojnicima u Osijeku vidi: Kamilo Firinger, „Napoleonovi vojnici u Osijeku“, Osječki zbornik 1 (1942), 29-34. 
otuđiti imovina, dok su se dužnici mogli utamničiti tek nakon pravne procedure. Mogli su birati i biti birani u gradske službe, funkcija im je bila doživotna i mogli su biti razriješeni samo uz dozvolu i prethodno znanje vladara, dok su u sudskim sporovima bili podložni samo gradskom sucu, a bili su neovisni i o svim vojnim zapovjednicima. ${ }^{36}$ Bili su oslobođeni primanja bilo kojeg pripadnika staleža u svoj dom i „od ukonačivanja do primanja i gošćenja vojnika“, osim po odredbi magistrata. ${ }^{37}$ Osim prava, u Povelji su definirane i obveze građana: briga za unutrašnju sigurnost grada, obuzdavanje zločinaca, sprječavanje izgreda, postavljanje noćne straže te plaćanje javnih tereta, kako vojnih, tako i gradskih. ${ }^{38}$

Građanski status nije moglo steći cijelo gradsko stanovništvo. Prema srednjovjekovnoj tradiciji građaninom je mogla postati samo punoljetna osoba koja je živjela u gradu i nakon podnesene molbe primljena je u građanstvo, a zatim i upisana u popis građana, u slučaju Osijeka u Upisnik građana. ${ }^{39}$ Tada, za razliku od danas, nisu svi stanovnici gradova automatski postali i građani, već su ta prava bila „rezervirana“ samo za pojedince koji su zadovolji sve posebne uvjete, a to su: katolička vjeroispovijest, kućevlasništvo i neporočni način života na području grada barem godinu dana od podnošenja molbe. Pojedinac je trebao potjecati iz zakonitog braka, biti punoljetan, oženjen i imati slobodan status, što je podrazumijevalo da nije bio kmet ili da nije uživao građanska prava nekog drugog grada. ${ }^{40}$

Te se odredbe mogu primijeniti i na osječke građane između 1809. i 1814. godine. Zahvaljujući reformskoj djelatnosti Josipa II. i objavi Edikta o vjerskoj toleranciji 1781. godine, građanski je status moglo steći i pravoslavno stanovništvo. Prema Povelji, uz rimokatolike i grkokatolike, oni su bili jedini koji su mogli posjedovati i nekretninu na području grada: „Dajemo na znanje spomenutoj gradskoj općini, da u istoj slobodnoj i kraljevskoj općini Osijek ne može nitko drugi primiti stanovanja (inkolat), ni zemljište, ni državni posjed osim rimske ili grčko-katoličke ili grčko nesjedinjene vjeroispovijesti (pravoslavne). ${ }^{“ 41} \mathrm{Za}$ upisivanje vjeroispovijesti građana u Upisniku korištene su kratice: rimokatolici su upisani kao $R$. Catholicus, a pravoslavci kao G. R. N. U, odnosno Grci nesjedinjenog obreda. Od 569 upisanih građana,

\footnotetext{
${ }^{36}$ Isto, 59.

${ }^{37}$ Isto, 54-56, 58-63.

${ }^{38}$ Isto, 60.

${ }^{39}$ Zvjezdana Sikirić, „Građani Slobodnog i Kraljevskog grada Zagreba prema Knjizi građana (1733-1799)“, Radovi Zavoda za hrvatsku povijest Filozofskog fakulteta Sveučilišta u Zagrebu, Vol. 29 No. 1 (1997), 103.

${ }^{40}$ Isto, 106.

${ }^{41}$ Sršan, Slobodni i kraljevski grad, 62.
} 
$163(28,64 \%)$ su pravoslavne vjeroispovijesti, a 404 su rimokatolici (71\%), dok je u dviju osoba vjerski status nepoznat. ${ }^{42}$ Ti podatci svjedoče da su se u građanstvo većinom primali rimokatolici, što se može objasniti i time što je glavnina osječkog stanovništa bila te vjeroispovijesti. Pravoslavno se stanovništvo u zagrebačku Knjigu građana počelo upisivati od 1785. godine, iako im je broj bio znatno manji u odnosu na Osječane jer ih je do kraja 18. stoljeća upisano tek $11 .{ }^{43}$

U osječkom se Upisniku građana u promatranom razdoblju pojavljuju tri kategorije bračnoga statusa: oženjen, samac i udovac. U upisima prednjače oženjeni građani, s 553 upisa, zatim ih slijede samci (13 osoba) i udovci (3 osobe). Iz toga se može zaključiti da brak nije bio jedan od najvažnijih preduvjeta za stjecanja građanskog statusa jer su se u pojedinačnim slučajevima činile i iznimke, što potvrđuju upisi samaca i udovaca.

Upisnik građana ne daje podatke o kućevlasništvu, nego je usmjeren na zanimanje građana, što je i logično jer se zahvaljujući tim zanimanjima ostvaruju prihodi koji omogućuju isplatu pojedinih davanja. Imajući u vidu zanimanja kojima su se bavili građani te geografski smještaj Osijeka i njegovu važnost u tranzitnoj trgovini, može se zaključiti da je većina ljudi taj status zatražila radi određenih olakšica, što naglašava i Povelja: „,...) jer je grad, zbog svojeg prirodnog položaja na obali rijeke Drave, prikladan za uvoz prirodnih proizvoda i rukotvorina iz susjednih krajeva, no u prvom redu za njihovo izvozenje u susjedne i udaljene pokrajine ${ }^{\text {“ }}{ }^{44}$ Naravno, gospodarski procvat grada bio je drag i Habsburgovcima jer su u kriznim vremenima mogli računati na prihode svojih gradova.

Prije stupanja u gradsku svezu svaka je osoba trebala dokazati da živi neporočnim načinom života i da je dostojna biti građaninom Slobodnog i kraljevskog grada Osijeka. Onim pojedincima koji taj kriterij nisu zadovoljili molba je bila odbijena te su ju mogli ponovno podnijeti, a ako su u međuvremenu ispunili taj zahtjev. Ako su svi uvjeti bili zadovoljeni, magistrat bi utvrdio da su kandidati prikladni za dobivanje građanskog statusa te su trebali priložili prisegu. Nakon toga im se ime unosilo u popis građana te im se izdavala potvrda.

Bilo je i onih koji su živjeli poročnim načinom života pa im je molba odbijena. Takav je bio, primjerice, spomenuti Jakob Janić, koji je živio neprimjereno, a zbog čega mu je molba odbijena, ,dok se ne popravi““ ${ }^{45}$ Iz toga

\footnotetext{
${ }^{42}$ HR-DAOS-6.1.6, knj. 460.

${ }^{43}$ Sikirić, „Građani Slobodnog i Kraljevskog grada“, 106.

${ }^{44}$ Sršan, Slobodni i kraljevski grad, 53.

${ }^{45}$ Političko-gospodarski zapisnici, 167.
} 
pak slijedi da odbijena molba nije značila da se osoba nikada više ne može primiti u građansku svezu, već suprotno. Molba se mogla predati više puta, i to do stjecanja zadovoljavajućih uvjeta. Gradski magistrat nije kontrolirao samo građane, već sve stanovnike na području grada. Ta se kontrola najviše odnosila na strance. Godine 1809. Đuro Meltzer i Gašpar Brkić uhvaćeni su na području grada te su intitulirani kao lutalice jer su „,njihove putovnice pronađene oštećene zbog defekta potpisa te su stavljeni pred sud i ispitani glede zakonitosti putovnica". ${ }^{46}$ Unatoč tome što su se dvojica izjasnila kao stanovnici Vinkovaca, magistrat je, putem dopisa Brodske pukovnije, zatražio potvrdu njihova identiteta. Sličan je slučaj i Tamaška Miške, koji je zbog neposjedovanja putovnice uhvaćen kao lutalica te je ispitan pred sudom. Njegove navodeda je rođen u Egerazu na području Baranjske županije i da mu ondje živi i otac i njegova obitelj, žena s dvoje djece - magistrat je dao provjeriti. Iz zatvora je pušten tek kada su mu roditelji po dopisu mjesnog župnika poslali ispravu o njegovu identitetu. ${ }^{47}$

\section{Građani Slobodnog i kraljevskog grada Osijeka}

\subsection{Statistički podaci o osječkom građanstvu između 1809. i 1814. godine prema broju građana, vjerskoj $i$,nacionalnoj ${ }^{648}$ pripadnosti}

Promatrajući po godinama, između 1809. i 1814. godine u Upisnik građana upisano je 569 osoba. Te su osobe zadovoljile sve prethodno navedene uvjete za pozitivno rješenje njihovih molbi kao jamca za ostvarenje određenih privilegija, ali i obveza, što ih je propisala Povelja. Statistički gledano, prema rubrikama Upisnika osječko je građanstvo moguće promatrati na osnovi nekoliko kategorija: po njihovu broju, vjerskoj i nacionalnoj pripadnosti i zanimanju. Promatrajući po godinama, uočava se da je broj građana između 1809. i 1814. godine varirao, što dokazuju i podaci Grafikona 1.

Iz podataka grafikona vidljivo je da je najviše pojedinaca građanski status steklo 1809. i 1810. godine. U tim je dvjema godinama upisano ukupno 454 osoba ( $80 \%$ ), dok je u sljedećim četirima godinama taj broj bio znatno manji, tj. upisano je ukupno 113 osoba (20 \%). Iz toga se može zaključiti da je, u odnosu na 1809. i 1810. godinu, interes za građanski status u narednim godinama bio otprilike peterostruko manji te da pokazuje konstantan pad. Izuzetak je 1813. godina, kada je u odnosu na prethodnu i sljedeću godinu upisano nešto više građana, njih 42.

${ }^{46}$ Prvi zapisnik, 205.

${ }^{47}$ Isto, 247, 285.

${ }^{48}$ Pojam je stavljen pod navodnike jer u tome vremenu ne postoji pojam nacije u današnjem smislu riječi, što najbolje dokazuje i Upisnik građana jer je u njemu „natio“ određen na nekoliko načina: prema pripadnosti nekom narodu, državi, gradu, ali i pokrajini. 
Grafikon 1. Broj dodijeljenih građanskih statusa po godinama49

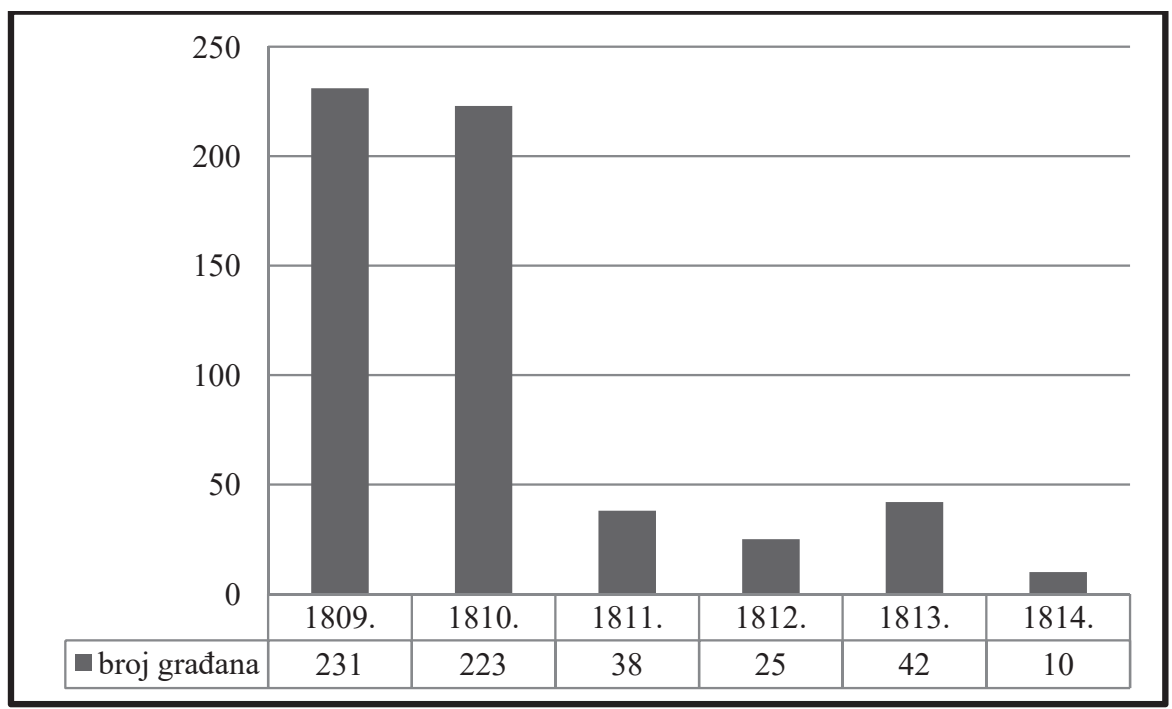

Uzrok pada broja građana može se tumačiti na više načina. S jedne strane, svi koji su ostvarili formalne uvjete za stjecanje građanskog prava svoju su molbu predali odmah: ili 1809. ili 1810. godine, a kako im je molba odobrena, mogli su i prisegnuti, te se broj takvih ljudi u gradu smanjio. S druge strane, pak, treba imati na umu da se pojam građanina od kraja 18. pa sve do prve polovice 19. stoljeća mijenjao. Pravo na slobodu i privatno vlasništvo nisu imali samo građani, već svi koji su se bavili obrtom i trgovinom te koji su od svojih prihoda mogli dostojno živjeti. U srednjem i u ranom novom vijeku većina je građana bila i član nekog ceha, a time je na tržištu bila isključena konkurencija, što je pojedince sputavalo u naglom bogaćenju i proizvodnji viškova. Od početka 19. stoljeća sve se manji broj ljudi želi udružiti u ceh, pa tako razvoj njihove gospodarske djelatnosti ne sputavaju razna pravila, tj. među pripadnicima različitih zanimanja počela se razvijati konkurencija. Moderni pojam građanstva označavao je ulaganje u više obrta ili ulaganje $u$ obveznice, a čime su se stvorili preduvjeti za naglo bogaćenje pojedinaca. Iz toga slijedi da se formalno-pravni pojam srednjovjekovnog građanina usljed novih gospodarskih i privrednih prilika počeo mijenjati te je sve više bio nominalnog karaktera. Većina je stanovništva, koja nije stupila u građanstvo, zahvaljujući nestanku granica između društvenih slojeva, mogla uživati gotovo sva prava i privilegije kao i građani, a izbjegavši plaćanje određenih nameta koji su građanima bili propisani. ${ }^{50}$

\footnotetext{
${ }^{49}$ HR-DAOS-6.1.6, knj. 460.

${ }^{50}$ Bácskai, Városok Magyaroszágon, 42-45, 125-132.
} 
Prema odredbama Povelje, na području grada nekretninu su mogli posjedovati pripadnici samo triju vjeroispovijesti: rimokatolici, grkokatolici i pravoslavci. Promatrajući podatke koji se odnose na vjersku pripadnost građana između 1809. i 1814. godine, vidljivo je da su samo pripadnici dviju religija, rimokatolici i pravoslavci, stekli građanska prava. Odnose u broju pripadnika tih religija prikazuje Grafikon 2.

Grafikon 2. Klasifikacija građana prema vjeroispovijesti po godini stupanja u gradsku svezu ${ }^{51}$

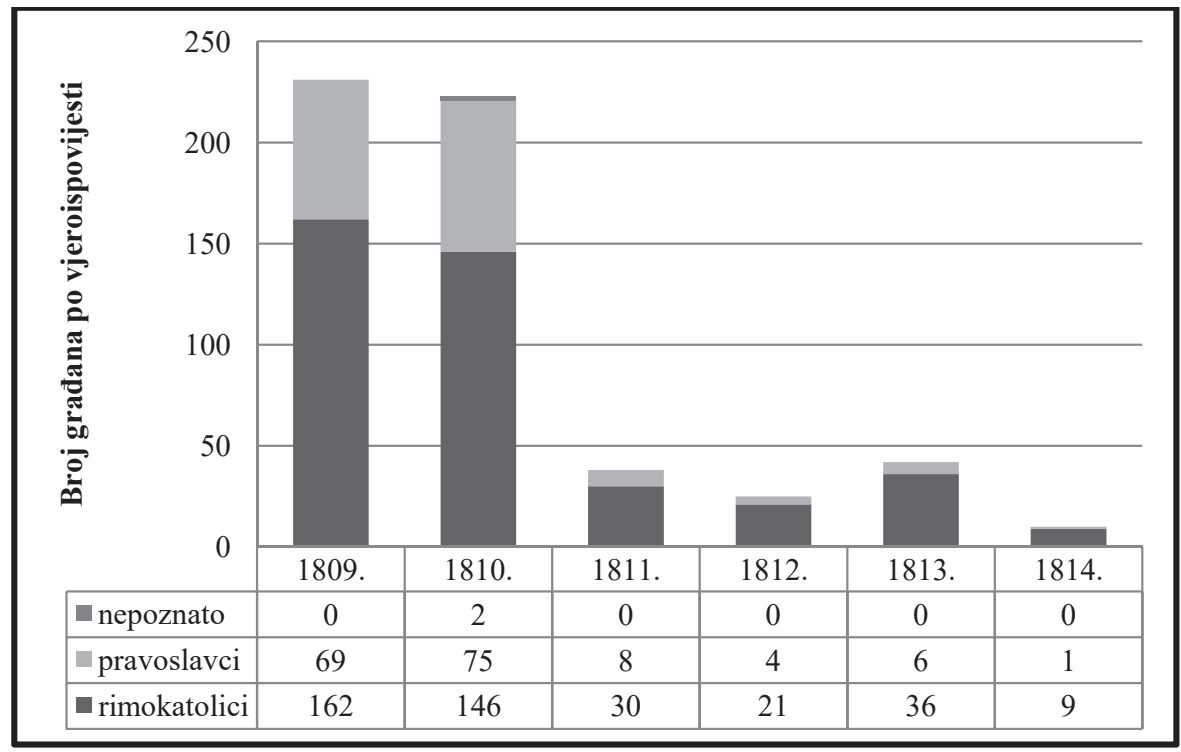

Prema podacima grafikona vidljivo je da je kod 99,64 \% građana upisana vjeroispovijest. Taj podatak nedostaje samo kod dviju osoba iz 1810. godine: kod Mathiasa Bosnjakovicsa, kod kojeg nije zabilježeno ni zanimanje, i kod trgovca Bartolovics Joannesa. Promatrajući po godina, vidljivo je da u cijelom promatranom razdoblju među osječkim građanstvom prevladava jak katolički element. Prema podacima grafikona najveća je razlika u broju katoličkih i pravoslavnih građana bila između 1811. i 1814. godine, kada je kod pojedinih godina, npr. 1812. i 1813. godine, broj rimokatolika bio peterostruko veći od broja pravoslavaca. Istaknuti katolički element ne iznenađuje ako se ima u vidu da su do 1781. godine samo katolici mogli steći građanski status. Nadalje, prema 7. članku Povelje, Osijeku je „,dopušteno patronatsko pravo i predlaganje rimokatoličkih župnika po katoličkim građanima i stanovnicima, dok je Crkva na području Osijeka i dalje imala pravo ubiranja crkvene desetine“. 52

\footnotetext{
${ }^{51}$ HR-DAOS-6.1.6, knj. 460.

${ }^{52}$ Sršan, Slobodni i kraljevski grad, 59.
} 
Osim toga, ne smije se zaboraviti ni višestoljetna privrženost Habsburške dinastije Katoličkoj Crkvi, koja je dominirala tijekom čitave njihove vladavine.

Kako je u prvim desetljećima 19. stoljeća pojam narodnosti ili nacionalnosti bio nepoznat, za označavanje narodnosti u Upisniku često su se rabili nazivi prema regionalnim područjima, nazivima gradova i pokrajina, ili je kao naziv pripadnosti upisan samo grad ili država odakle je pojedinac potekao. Tzv. nacionalnu pripadnost osječkih građana između 1809. i 1814. godine u Upisniku je lako pratiti jer taj podatak nedostaje samo kod šeširdžije Joannesa Omerzya, koji je 1810. godine stekao građanski status, dok je taj podatak kod ostalih 568 osoba evidentiran. Upisnik u promatranom razdoblju poznaje 19 kategorija narodnosti, a to su sljedeće: Austrijanac, Osječanin, Bavarac, Bosanac, Baranjac, Čeh, iz Götschena, Hrvat, Ilir, Sveto Rimsko Carstvo Njemačke Narodnosti, Talijan, Mađar, Makedonac, Moravljanin, Nijemac, Slaven, Slavonac, Štajerac i Tirolac. ${ }^{53}$ Udio pojedinih pripadnika određenoj kategoriji u promatranom razdoblju prikazuje Grafikon 3.

Grafikon 3. Udio narodnosti u osječkom Upisniku građana između 1809. i 1814. godine ${ }^{54}$

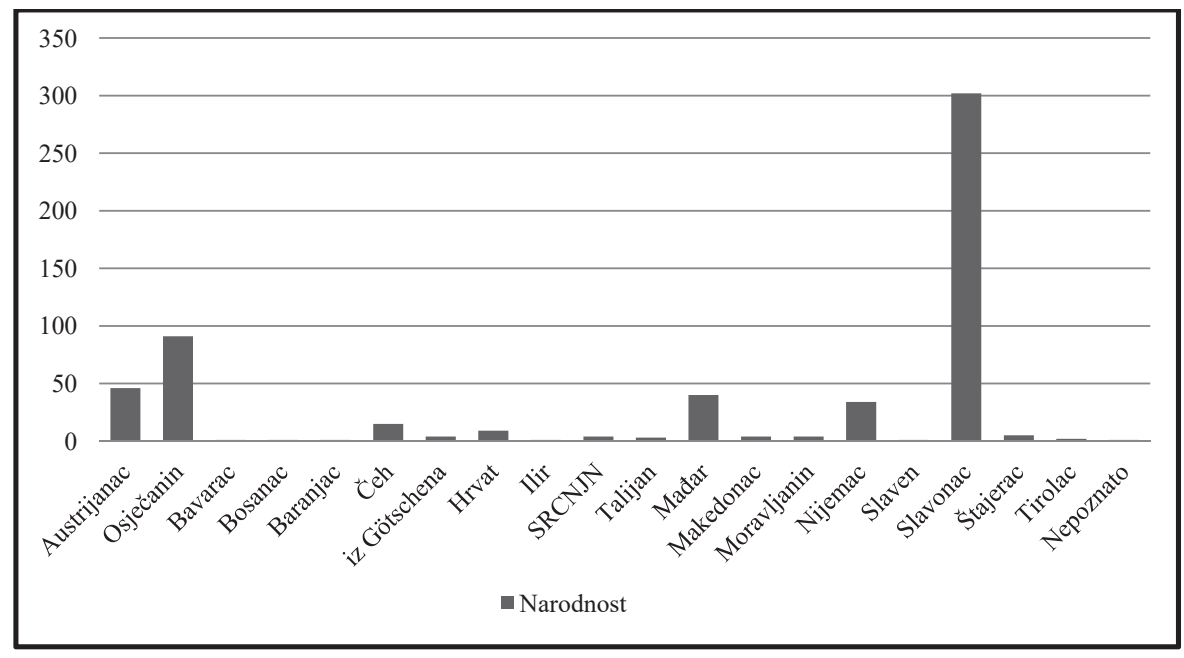

Prema podacima grafikona vidljivo je da je magistrat građanski status najviše dodjeljivao domaćem stanovništvu: Slavoncima i Osječanima. Više od polovice (53\%) dodijeljenog građanskog prava pripalo je Slavoncima, dok su na drugom mjestu Osječani sa $16 \%$. Od stranaca, najviše je upisano $\mathrm{Au}-$ strijanaca (8 \%), Mađara (7 \%) i Nijemaca $(5,7 \%)$. Iz podataka je vidljivo da je Osijek bio privlačniji tadašnjem srednjoeuropskom stanovništvu, što doka-

\footnotetext{
${ }^{53}$ Za točan broj pripadnika pojedine nacionalnosti vidi Prilog 1 na kraju rada.

${ }^{54}$ HR-DAOS-6.1.6, knj. 460.
} 
zuje i mali broj prisutnih građana s područja jugoistočne Europe. U izvoru se spominje samo jedan Bosanac, Antonius Jerxabek, katolik, oženjen, po zanimanju svratištar, a građanski je status stekao 1809. godine. S područja jugoistočne Europe u gradu su još građanski status stekla četvorica Makedonaca. Iz navedenih podataka može se zaključiti da je osječki magistrat u građanstvo većinom primao domaće stanovništvo, jer ih je u popisima ukupno 67,44 \%. U taj su postotak ubrojeni Osječani, Slavonci i Hrvati.

Promatrajući stalešku pripadnost osječkih građana, može se zaključiti da su građanski status zatražili neplemeniti stanovnici. Od pripadnika staleža valja spomenuti plemstvo. Između 1809. i 1814. godine zabilježeno je 18 plemića s građanskim statusom. Većina njih obavljala je najveće dužnosti, od dvorskog zastupništva do funkcije osječkog gradskog suca. Ako su posjedovali zemljište na području grada, zakonski su potpali pod gradsku sudbenost te su, kao svi ostali građani, trebali snositi sve gradske terete koji su bili vezani za njihovo zemljište. ${ }^{55}$ Između 1809. i 1814. godine u Slobodnom i kraljevskom gradu Osijeku ni jedan oslobođeni kmet, ali ni sin građanina, nije stekao građanski status.

\subsection{Zanimanja osječkih građana}

U Upisniku građana peti je stupac bio predviđen za upisivanje podataka o zanimanju ili pak statusu građanina. Osim zanimanja, u tu se rubriku upisao i podatak ako je pojedinac bio i elector civis. Podatci su redovito evidentirani, samo kod 7 osoba nedostaje podatak o zanimanju. Glavnina osječkih građana bavila se samo jednom vrstom djelatnosti, ali je bilo i pojedinaca koji su se bavili dvama obrtima. Među njima se ističe Branstadter, Franciscus, Moravljanin, katoličke vjeroispovijesti, koji je bio i gostioničar i voskar. Prema upisanim podacima, osječki se građani prema zanimanju mogu podijeli u četiri skupine: zemljoradnike, obrtnike, trgovce i školovane ljude.

Premda se većina osječkih građana bavila obrtom i trgovinom, među njima je bio znatan broj onih koji su se bavili i zemljoradnjom - od 569 građana, njih 41 (i većinom su bili Slavonci). Podaci o zemljoradnicima govore o tome da su pojedinci svoje prihode ostvarivali tradicionalnim gospodarskim djelatnostima; obrađivanjem zemlje i prodajom poljoprivrednih proizvoda.

\subsubsection{Obrtnici}

U promatranom razdoblju, a prema podatcima Upisnika, najveći dio osječkih građana, njih $346(60,80 \%),{ }^{56}$ bavio se nekom vrstom obrta. Pro-

${ }^{55}$ Sršan, Slobodni i kraljevski grad, 61.

${ }^{56}$ Analiza uključuje samo one obrtnike koji su stekli status građanina u promatranom razdoblju. 
matrajući po godinama, najveći broj obrtnika građanski je status stekao 1810 . godine, njih 137 (39,59\%), dok ih je najmanje bilo 1814. godine, kada ih je prisegnulo samo $7(2,02 \%)$. Grafikon 4 paralelno prikazuje broj građana $\mathrm{i}$ obrtnika prema godišnjoj distribuciji između 1809. i 1814. godine.

Grafikon 4. Broj građana i obrtnika između 1809. i 1814. godine ${ }^{57}$

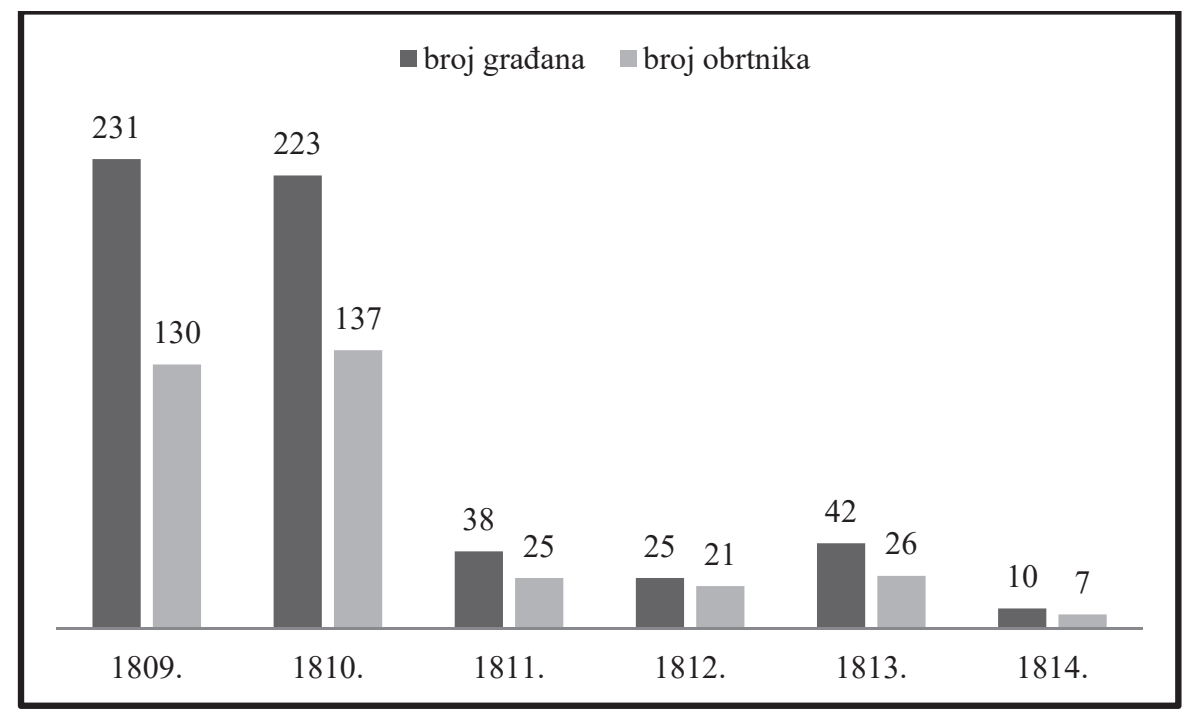

Iz podataka grafikona vidljivo je da je s padom broja građana ravnomjerno padao i broj obrtnika. Izuzetak je samo 1810 . godina, kada je, u odnosu na prethodnu godinu, broj obrtnika veći, a broj građana manji. Povećanje njihova broja u odnosu na 1809. godinu nije velik jer je upisano tek 7 obrtnika više. Od 1811. od 1814. godine ${ }^{58} \mathrm{~s}$ padom broja građana ravnomjerno se smanjuje i broj obrtnika. ${ }^{59}$

U Upisniku građana evidentirano je 51 obrtničko zanimanje: ${ }^{60}$ bačvar, bravar, čarapar, češljar, čizmar, dimnjačar, duhanar, gostioničar, gumbar, kazandžija, knjigoveža, kočijaš, kolar, kirurg/brijač/ranarnik, kositrar, kovač, kožar, krojač, krznar, limar, lončar, mesar, mlinar, mrežar, pekar, pivar, pokrivar, postolar, puškar, rekljar/kožuhar, remenar, rešetar, ribar, sapunar, slikar,

${ }^{57}$ HR-DAOS-6.1.6, knj. 460.

${ }^{58}$ Za točan broj distribucije obrtničkih zanimanja po godini vidi Prilog 3 .

${ }^{59} \mathrm{O}$ broju obrtnika podatke donosi i popis Josipa II. iz 1786. godine. O tome više: Imre Odor, „Osijek u doba cara i kralja Josipa II. 1786. godine“, Glasnik arhiva Slavonije i Baranje 4 (1997), 170-182.

${ }^{60}$ Prilog 2 sadržava sve osječke obrte evidentirane u ovom razdoblju na hrvatskom i latinskom jeziku. 
staklar, štavljač kože, stolar, suknar, svratištar, šeširdžija, tesar, tokar, tkalac, urar, užar, voskar, zlatar i žutomjedar. ${ }^{61}$ Navedena zanimanja ukazuju na razgranatost osječkog obrta, koji je svojom raznovrsnošću nastojao udovoljiti svim potrebama osječkog stanovništva, od onih prehrambenih, preko obućarsko-odjevnih, pa sve do izrade luksuznih proizvoda, što svjedoči i postojanje zlatarskog obrta na području grada. Analizirajući gore navedena zanimanja, može se zaključiti da zbog sve zahtjevnijeg načina života gradskoga stanovništva dolazi do specijalizacije u pojedinim zanatima, što rezultira pojavom novih obrtničkih zanimanja, ali i podjelom posla i zapošljavanjem više ljudi. ${ }^{62}$

Promatrajući pojedinačna obrtnička zanimanja u Upisniku građana, uočava se da se najveći broj osječkih građana bavio uslužnim obrtom, a od kojih se ističu svratištari. U izvoru ih je navedeno 48, od kojih je 46 rimokatolika, a tek dvojica pravoslavaca. U odnosu na njihovu homogenu vjersku pripadnost, njihova je „nacionalna“ pripadnost vrlo heterogena. Među njima prednjače Slavonci (17), zatim Mađari (8) i Nijemci (7), a koje slijede Osječani (5), Austrijanci (5), Česi (2), Hrvati (1) i Bosanci (1). Tim su se obrtom bavili i Franciscus Devous i Georgius Klee. Obojica su postali građani 1809. godine, a njihova je narodnost upisana kao Sveto Rimsko Carstvo Njemačke Narodnosti, što je, u usporedbi s navedenim pripadnostima, najširi pojam. Velik broj svratištara ukazuje na to da je Osijek bio regionalni centar, i to ne samo u političko-gospodarskom, već i u kulturnom i vojnom smislu, te da je zbog dolazaka velikog broja stranaca morao osigurati dovoljan broj smještaja. Uslužnim zanimanjem bavili su se i gostioničari (12) i kočijaši (3). U tim su zanatima, kao i u prethodnom, dominirali Slavonci, Mađari i Austrijanci.

Među osječkim građanstvom najviše se obrtnika bavilo zanimanjima koja su proizvodila predmete široke upotrebe, a prednjačili su građani u obućarskoodjevnom obrtu (ukupno ih je 134), čija je glavna zadaća bila izraditi različitu odjeću i obuću. Riječ je o struci koja objedinjuje više zanimanja: krojače, čarapare, remenare, gumbare, postolare, čizmare, tkalce, šeširžije, rekljare i druge. Osim za potrebe osječkoga stanovništva, postolari su trebali izrađivati i vojne čizme. Prema dopisu gospodarskog povjerenstva Donje Austrije 22. rujna 1809., a koje se tada nalazilo u Novom Sadu, njegovi su članovi od osječkog ceha postolara tražili da im izrade vojne čizme, a za par čizama htjeli su platiti jednu forintu. Isto tako, tražili su od njih da za to pronađu i kožu. Ceh je tom cijenom bio nezadovoljan pa je, pozivajući se na cijenu krzna koja je potrebna za njihovu izradu, za svoj rad tražio 1 forintu i 45 križara. ${ }^{63} \mathrm{I} \mathrm{u}$ zagrebačkoj Knjizi građana u broju obrtnika prednjačili su građani u obućar-

\footnotetext{
${ }^{61}$ HR-DAOS-6.1.6, knj. 460.

${ }^{62}$ Sikirić, „Građani Slobodnog i Kraljevskog grada“, 113.

${ }^{63}$ Prvi zapisnik, 79, 191.
} 
sko-odjevnom obrtu, no, za razliku od osječkih obrtnika, u njih je postojala i razlika u izradi pojedinih predmeta. Toj skupini pripadaju i postolari, koji su se prema načinu izrade obuće dijelili na tzv. njemačke i mađarske postolare. Razlika u izradi cipela očituje se u tome što su „njemački“ postolari izrađivali skuplje cipele, a „mađarski“ jeftinije. Takvoj razlici podliježu i krojači, među kojima se prema tehnici izrade isto razlikuju ,njemački“ $i$, ,mađarski““.64

Prehrambenim se obrtom bavilo 52 upisanih građana. Među njima prednjačili su ribari (njih 20), što potvrđuje da je na osječko građanstvo pri izboru zanimanja utjecala i okolina, a u ovom slučaju blizina rijeke Drave, koja je bila pogodna za ribarenje. To je struka kojom se bavilo isključivo domaće stanovništvo: Slavonci (17) i Osječani (3). Po brojnosti, na drugom su mjestu bili mesari (njih 11), a pravo na sječu mesu građani su stekli tek 1809. godine. Mesarenje se često pojavljuje kao predmet u spisima magistrata, a uglavnom se radi o tužbama. Tužbu su podnijeli 1812. godine gornjogradski mesari Pavao i Šimun Mohačanin i Petar Putnik. Tužili su se magistratu na (također gornjogradskog) mesara Michaela Frölicha jer je otvorio dvije mesnice na, kako kažu, njihovu štetu i od magistrata su tražili da drži otvorenom samo jednu. Magistrat je njihov zahtjev odbio, obrazloživši svoju odluku time „da će se putem više mesnica bolje i prikladnije javnost snabdijevati mesom" ${ }^{65}$ Njih slijede mlinari (10), pekari (8) i pivari (3). U tim su obrtima također prednjačili „,domaći“ građani. Mlinari su, osim za potrebe osječkog stanovništva, trebali proizvesti brašno i za potrebe države. To je često dovodilo do sukoba te su magistratu često dolazile pritužbe na rad mlinara, kako su vrlo spori i nemarni. ${ }^{66}$

Ako je govor o ostalim zanimanjima, različitim vrstama metalnog obrta bavilo se 27 građana, drvodjelskim 19, građevinskim samo dvojica. Postoje i obrtnička zanimanja ${ }^{67}$ koja imaju samo jednog predstavnika među osječkim građanstvom, a svi su stranog podrijetla: dimnjačar (Austrijanac), duhanar i knjigoveža (obojica su Česi), mrežar (Baranjac) i slikar (Mađar). Zahtjevnijim obrtničkim djelatnostima bavili su se stranci. U tu se skupinu ubrajaju, na primjer, urari, ${ }^{68}$ a među građanstvom bila su samo dvojica: Austijanac Kraker, Paullus i Nijemac Seidl, Jonnes, obojica oženjeni. ${ }^{69}$ Iz toga se može zaključiti da u obrtima masovne proizvodnje prednjače ,domaći“ građani, dok su pred-

${ }^{64}$ Sikirić, „Građani Slobodnog i Kraljevskog grada“, 112.

${ }^{65}$ Političko-gospodarski zapisi, 354.

${ }^{66}$ Prvi zapisnik, 117.

${ }^{67}$ U Upisniku građana spominju se još:pokrivari (3), sapunari (3), sedlari (3), staklari (5), užari (4), voskari (4).

${ }^{68} \mathrm{O}$ urarima više: Kamilo Firinger, „Satovi i urari u Osijeku u 18. i na početku 19. stoljeća“, Osječki zbornik 1 (1967), 29-34.

${ }^{69}$ HR-DAOS-6.1.6, knj. 460. 
stavnici najmanje zastupljenih obrta među građanstvom doseljenici. Posebnu skupinu obrtnika činili su tzv. kirurzi/ranarnici, koji su bili brijači, ali su obavljali i manje zahvate (vadili zube, amputirali udove, liječili rane, puštali krv). ${ }^{70}$ Njih je u promatranom razdoblju bilo osmero: Slavonac Czigler, Josephus, Osječani: Resch, Jacobus i Rathgeb, Volfgangus, Mađari: Gast, Josephus, Folk, Antonius i Arva, Joannes te Nijemci: Schott, Franciscus i Pilinger, Petrus. U tom su obrtu isto prednjačili stranci.

\subsubsection{Trgovci}

Druga najbrojnija skupina prema Upisniku građana bili su trgovci. Između 1809. i 1814. zabilježena su 104 trgovca s građanskim statusom. Grafikon 5. prikazuje broj trgovaca-građana u odnosu na obrtnike i na ukupan broj građana u promatranom razdoblju.

Grafikon 5. Ukupan broj građana, obrtnika i trgovaca u osječkom Upisniku u promatranom razdoblju ${ }^{71}$

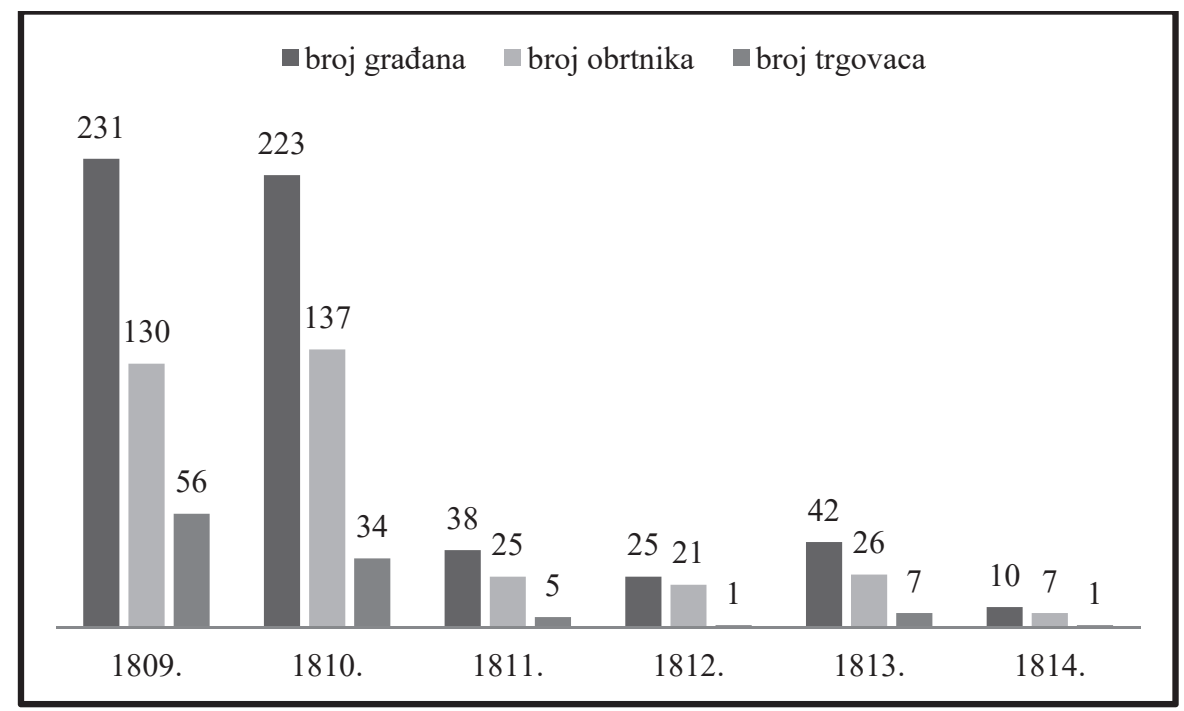

Prema podatcima grafikona vidljivo je da je u svakoj godini broj trgovaca bio manji u odnosu na obrtnike. Najveći broj trgovaca stekao je građanski status 1809. godine, kada je njih 56 dalo građansku prisegu. Najmanje je trgovaca zabilježeno 1812. i 1814. godine, kada je za svaku godinu upisan samo jedan trgovac. U promatranom razdoblju broj trgovaca-građana postupno se smanjuje. Izuzetak je samo 1813. godina, kada je evidentirano sedmero trgo-

\footnotetext{
$\overline{70}$ Sikirić, „Građani Slobodnog i Kraljevskog grada“, 113.

${ }^{71}$ HR-DAOS-6.1.6, knj. 460.
} 
vaca. Doprinos razvoju i obrta i trgovine dala je osloboditeljska Povelja 1809. godine, kada je ukinut niz carina na uvoz i izvoz robe. Važnost je toga prepoznao i car Franjo I. jer je u Povelji napomenuo da „obrt i trgovina doprinose blagostanju kralja i naroda“ i da su „prvi temelji procvata države“ i da će se „uz porast trgovine povećat i promet novca, koji je glavni temelj bogatstva, osobito u onim krajevima koji su bili (...) tlačeni turskim jarmom“. ${ }^{72} \mathrm{Na}-$ ravno, to je vrijedilo i za Osijek. Osim što je geografski položaj Osijeka bio prikladan za transport robe na kopnu, transport se, zahvaljujući rijeci Dravi, mogao odvijati i na vodi, što je omogućilo dobavljanje različite robe iz udaljenijih krajeva.

Kao i u Zagrebačkoj knjizi građana, i u osječkom se Upisniku pojavljuju dva naziva za trgovce: mercator i questor..$^{73}$ Nazivom mercator označeno je 82 građana, a questorom 22. Svi questori pripadali su domaćem građanstvu: među njima je bio 21 Slavonac, od kojih jedan Osječanin. Većina ih je pravoslavne vjeroispovijesti, a samo su petorica upisana kao rimokatolici. Iz toga se može pretpostaviti da se taj naziv najviše rabio za domaće trgovce, većinom pravoslavne vjeroispovijesti. ${ }^{74}$ Takva je bila praksa upisivanja i zagrebačkih pravoslavnih trgovaca u Knjigu građana.$^{75}$ Svi su osječki questori bili oženjeni i za svoj su građanski status platili 8 forinti.

Sastav osječkih trgovaca (mercator), u odnosu na questore, bio je raznovrsniji i većina je njih, osim trgovačke djelatnosti, obavljala dužnosti i unutar poglavarstva: od njih, 16 su već radili u gradskoj službi, dok će tu dužnost od 1816. godine među popisanima obavljati i Mohacsi, Stephanus i Mohl, Elias, a od 1821. godine Mihalovics, Georgius. Trgovac s građanskim pravom bio je i Czach, Michael, koji je u Osijeku imao ulogu inspektora gradske bolnice, a bio je i siročadski skrbnik. ${ }^{76}$ Iz toga se može zaključiti da je u redovima trgovaca bila prisutna tadašnja „elita“ Slobodnog i kraljevskog grada Osijeka. To u Upisima potvrđuju i plemići s građanskom statusom koji su se također bavili trgovačkom djelatnošću: Cambezy, Nicolaus, Jurkovits, Basilius i Knezevics, Kasimirus, koji su za svoj građanski status platili 25 forinti. ${ }^{77}$

Nositelji su trgovačke djelatnosti u Osijeku bili „domaći“ građani, a među njima prednjače Slavonci (52 osobe) i Osječani (17 osoba). Također, među njima je bilo 13 stranaca različite nacionalne pripadnosti: Mađari (4), Make-

\footnotetext{
72 Sršan, Slobodni i kraljevski grad, 51, 53.

${ }^{73} \mathrm{U}$ promatranom su razdoblju u Upisniku upisane 3 osobe koje su ,institori“, odnosno poduzetnici. Sva trojica su Mađari, rimokatoličke vjeroispovijesti i oženjeni.

${ }^{74}$ HR-DAOS-6.1.6, knj. 460.

${ }^{75}$ Sikirić, „Građani Slobodnog i Kraljevskog grada“, 115.

${ }^{76}$ HR-DAOS-6.1.6, knj. 460.

${ }^{77}$ Isto.
} 
donci (4), došljaci iz austrijskog Gotschena (2) i po jedan Štajerac, Talijan i Nijemac. Zanimljivo je primijetiti da je kao Mađar upisan i Demetrovics, Georgius, oženjeni trgovac pravoslavne vjeroispovijesti. ${ }^{78}$ Promatrajući vjerski sastav stanovništva, vidljivo je da među njima prednjači osječko pravoslavno građanstvo. Među trgovcima bilo ih je 73,13 \%, a ako im se pribroji i 17 pravoslavnih questora, dobiva se podatak da su između 1809. i 1814. godine nositelji trgovačke djelatnosti bili pravoslavni građani. ${ }^{79}$ Naime, od 104 mercatora i questora 77 (74 \%) je pravoslavaca, 26 rimokatolika (25\%), a samo je vjerska pripadnost trgovca Bartolovicsa, Joannesa, koji je postao građanin 1810. godine, ostala nepoznata. ${ }^{80}$

\subsection{3. Školovani ljudi}

Zahvaljujući upravnim reformama Marije Terezije i Josipa II., na području Habsburške Monarhije postojala je sve veća potreba za školovanim službenicima koji su radili u državnim uredima. Potrebe za školovanim kadrom bilo je i na dvoru. Naravno, ne treba zanemariti ni kler, koji je i dalje bio jedan od najobrazovanijih slojeva društva. Terezijanskom reformom školstva ${ }^{81}$ škole su se otvorile i nižim slojevima društva, dok je Josip II. dopustio i kmetovima da izuče zanat ili da posjećuju višu školu. ${ }^{82}$ Niži društveni slojevi uputili su se u škole u nadi da će se zaposliti u uredu i time sebi i svojoj obitelji osigurati bolju egzistenciju. Školovanje je prije toga bilo predviđeno samo za plemstvo, ali ne zbog izučavanja neke struke ili prestiža, već stoga što je to podrazumijevala njihova staleška pripadnost. Izuzetak od toga na kraju 18. i na početku 19. stoljeća bilo je niže plemstvo koje, osim plemićkog statusa, često nije posjedovalo nikakva materijalna dobra. ${ }^{83}$

78 Isto.

79 O pravoslavnom elementu među osječkim građanstvom vidi: Josip Bösendorfer, „Pravoslavni element kao sekundarni faktor u oblikovanju građanskog staleža u Osijeku“, Osječki zbornik 1/2 (1948), 48-133.

${ }^{80}$ HR-DAOS-6.1.6, knj. 460.

${ }^{81} \mathrm{O}$ školstvu na hrvatskim prostorima napisano je više radova, između ostalog vidi: Franjo Emanuel Hoško, „Franjevci vode senjsku gimnaziju na prijelazu iz 18. i u 19. stoljeću“, Senjski zbornik Vol. 41., No. 1 (2014), 277-292; Dunja Modrić-Blivajs, „Utjecaj školskog zakonodavstva na razvoj školstva u Banskoj Hrvatskoj od 1774. do 1850. godine“, Povijesni prilozi Vol 32, No. 32 (2007), 209-220; Stjepan Sršan, „Državni nastavni planovi, programi i propisi na filozofskom i teološkom studiju u Đakovu početkom 19. stoljeća“, Diaconvensia: teološki prilozi, Vol. 14., No. 2 (2006), 259-284.

82 László Katus, A modern Magyarország születése, Magyarország története 1711-1914 (Pécs, 2010), 172.

83 Bácskai, Városok Magyarországon, 139-144. 
Među osječkim građanstvom najviše školovanih ljudi obavljalo je gradske funkcije. Na čelu gradskog poglavarstva bio je, kao gradski sudac, plemić Baranyay, Joannes, po narodnosti Mađar, zatim Slavonac Bogoevics, Petus u notarskoj službi, Slavonac Filkovics, Georgius, odvjetnik, Osječanin Goczinger, Franciscus, podrizničar, Czach, Michael, rizničar, a koji je bio i inspektor za gradsku bolnicu i skrbnik za osječku siročad, te naposljetku Liggatics, Vilhelmus kao gradski odvjetnik, odnosno fiškal. U gradskom su poglavarstvu na glavnim mjestima, osim na položaju gradskoga sudca, radili „,domaći“ ljudi. Na temelju tih funkcija vidljivo je da se većina ljudi u svome školovanju opredijelila za pravnu struku, što je početkom 19. stoljeća bilo prestižno zanimanje. Kao zanimanje spominje se i zastupnik. Pod tim je zanimanjem od 1809. do 1814. godine evidentirano 6 osoba. Od nižih uredskih službenika trebaju se spomenuti djelatnici pošte, tzv. postae officialisi. Do 1814. godine samo su dvojica djelatnika pošte stekli građanski status: Nijemac Mayerhoffer, Michael i Tirolac Schneider, Casparus. Njima su bili podređeni kuriri, tzv. veredariusi, a njih je među građanstvom bilo 20. U Slobodnom i kraljevskom gradu Osijeku građanski je status stekao i geometar Virovitičke županije, Mađar Hudovsky, Thomas. ${ }^{84}$

Prema Upisniku građana, zanimanja koja su se vezala za medicinu obavljali su stranci. U promatranom vremenu građanski su status stekla trojica apotekara: 1809. Čeh Fatz, Josephus, koji je bio i gradski zastupnik, a 1813. godine Nijemac Arno, Michael i Čeh Langer, Antonius. Podatci daju do znanja kako su vodeći gradski apotekari bili Česi. U odnosu na neškolovane ranarnike, u gradu je građanski status stekao liječnik Virovitičke županije, Austrijanac Neurohr, Matthias. Može se stoga zaključiti da su u medicinskoj struci najcjenjeniji bili stranci. ${ }^{85}$

\section{Zaključak}

Proglašenjem Osijeka slobodnim i kraljevskim gradom stvoreni su preduvjeti za stjecanje građanskog statusa osječkoga stanovništva, što je za posljedicu imalo niz privilegija za pojedince; od osobne slobode, preko neotuđivosti imovine, do neplaćanja određenih nameta. Podatci o osječkom građanstvu što ih ovaj rad sadrži nastali su analizom Upisnika građana, a zaključci koji se mogu donijeti jesu sljedeći: između 1809. i 1814. godine upisano je 569 osoba koje su zadovoljile sve uvjete potrebne za polaganje građanske prisege. Građanski je status, u pogledu staleške pripadnosti, steklo najviše neplemića, dok u promatranom razdoblju taj status nije stekao ni jedan sin građana, kao ni oslobođeni kmet. Zanimanja osječkog građanstva bila su različita.

\footnotetext{
${ }^{84}$ HR-DAOS-6.1.6, knj. 460.

${ }^{85}$ Isto.
} 
Prednjače obrtnici, a najbrojniji su pak oni koji su izrađivali proizvode široke upotrebe, tj. pripadnici tzv. obućarsko-odjevnog i prehrambenog obrta. Glavninu su obrtnika činili domaći ljudi. Drugi po zastupljenosti bili su trgovci. Predstavnici te struke bili su domaći ljudi, ali u toj djelatnosti, u usporedbi s obrtničkom, prednjače pravoslavni građani. U Upisniku su najmanje zastupljeni školovani ljudi. Obrazovani pojedinci koji su radili u poglavarstvu bili su domaći građani, dok su se stranci isticali u medicinskim djelatnostima kao apotekari i liječnici. Promotrivši nacionalnu pripadnost osječkog građanstva, može se zaključiti da je poglavarstvo u građanski status primalo razmjerno mnogo stranaca, ali u ukupnom su broju ipak prednjačili Slavonci, Osječani i Hrvati, tj. predstavnici domaćega stanovništva.

Ovo je istraživanje samo djelomičan doprinos istraživanju osječkoga građanstva. Otvara se, dakako, još niz istraživačkih pitanja na koja valja odgovoriti. Jedno od tih pitanja svakako je i pitanje odnosa osječkoga stanovništva prema građanskome statusu u cijeloj prvoj polovici 19. stoljeća te prate li stanovnici europski trend slabljenja interesa prema tom statusu. Nadalje, bilo bi zanimljivo istražiti kakva je bila struktura kućanstva osječkih građana. Komparacijom izvora, npr. Upisnika građana i popisa neplemenitog osječkog stanovništva iz 1814. godine, moglo bi se odgovoriti na neka od tih pitanja, dok bi se na primjeru gornjogradskog građanstva, uporabom spomenutih izvora i karte Gornjega grada, moglo provesti i istraživanje socijalno-topografskog karaktera. 
Prilog 1. Broj osječkih građana između 1809. i 1814. godine prema narodnostio6

\begin{tabular}{|l|c|c|c|c|c|c|c|}
\hline Narodnost & $\mathbf{1 8 0 9}$ & $\mathbf{1 8 1 0}$ & $\mathbf{1 8 1 1}$ & $\mathbf{1 8 1 2}$ & $\mathbf{1 8 1 3}$ & $\mathbf{1 8 1 4 .}$ & Ukupno \\
\hline Austrijanac & 25 & 16 & 1 & 1 & 2 & 1 & 46 \\
\hline Osječanin & 39 & 20 & 8 & 3 & 16 & 5 & 91 \\
\hline Bavarac & 1 & 0 & 0 & 0 & 0 & 0 & 1 \\
\hline Bosanac & 1 & 0 & 0 & 0 & 0 & 0 & 1 \\
\hline Baranjac & 0 & 0 & 0 & 0 & 1 & 0 & 1 \\
\hline Čeh & 9 & 5 & 0 & 0 & 1 & 0 & 15 \\
\hline iz Götschena & 4 & 0 & 0 & 0 & 0 & 0 & 4 \\
\hline Hrvat & 5 & 3 & 0 & 1 & 0 & 0 & 9 \\
\hline llir & 1 & 0 & 0 & 0 & 0 & 0 & 1 \\
\hline $\begin{array}{l}\text { Sveto Rimsko Carstvo Njemačke } \\
\text { Narodnosti (SRCNJN) }\end{array}$ & 4 & 0 & 0 & 0 & 0 & 0 & 4 \\
\hline Talijan & 1 & 1 & 1 & 0 & 0 & 0 & 3 \\
\hline Mađar & 18 & 13 & 3 & 5 & 1 & 0 & 40 \\
\hline Makedonac & 1 & 3 & 0 & 0 & 0 & 0 & 4 \\
\hline Moravljanin & 3 & 0 & 0 & 0 & 1 & 0 & 4 \\
\hline Nijemac & 15 & 6 & 2 & 2 & 9 & 0 & 34 \\
\hline Slaven & 1 & 0 & 0 & 0 & 0 & 0 & 1 \\
\hline Slavonac & 102 & 151 & 21 & 13 & 11 & 4 & 302 \\
\hline Štajerac & 1 & 3 & 1 & 0 & 0 & 0 & 5 \\
\hline Tirolac & $\mathbf{2 3 1}$ & $\mathbf{2 2 3}$ & $\mathbf{3 8}$ & $\mathbf{2 5}$ & $\mathbf{4 2}$ & $\mathbf{1 0}$ & $\mathbf{5 6 9}$ \\
\hline Nepoznato & & 1 & 0 & 0 & 0 & 0 & 2 \\
\hline Ukupno: & & & 0 & 0 & 1 \\
\hline
\end{tabular}

$\overline{{ }^{86} \text { HR-DAOS-6.1.6., knj. } 460 .}$ 
Prilog 2. Hrvatski i latinski nazivi obrtničkih zanimanja u Upisniku građana između 1809. i 1814. godine ${ }^{87}$

\begin{tabular}{|l|l|}
\hline \multicolumn{2}{|c|}{ Obrtnička zanimanja u osječkom Upisniku građana } \\
\hline hrvatski naziv & latinski naziv \\
\hline bačvar & vietor \\
\hline bravar & faber serarius \\
\hline čarapar & tibialifex \\
\hline češljar & pectinifex \\
\hline čizmar & cothurnarius \\
\hline dimnjačar & spacicaminarius \\
\hline duhanar & tabacarius \\
\hline gostioničar & caupo \\
\hline gumbar & nodularius \\
\hline kazandžija & cupri faber \\
\hline knjigoveža & bibliopega \\
\hline kočijaš & auriga \\
\hline kolar & rotarius \\
\hline kirurg/brijač/ranarnik & chyrurgus \\
\hline kositrar & stanarius \\
\hline kovač & faber ferrarius \\
\hline kožar & cerdo \\
\hline krojač & sartor \\
\hline krznar & pellio \\
\hline limar & laminarius \\
\hline lončar & figulus \\
\hline mesar & lanio \\
\hline mlinar & molitor \\
\hline mrežar & restiarius \\
\hline pekar & pistor \\
\hline pivar & braxator \\
\hline pokrivar & tegumentarius \\
\hline postolar & sutor \\
\hline puškar & sclopetarius \\
\hline rekljar/kožuhar & gausapearius/causapearius \\
\hline remenar & lorarius \\
\hline rešetar & cribrarius \\
\hline & \\
\hline
\end{tabular}

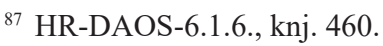




\begin{tabular}{|l|l|}
\hline ribar & piscator \\
\hline sapunar & smigmator \\
\hline sedlar & epiphiarius \\
\hline slikar & pictor \\
\hline staklar & vitrarius \\
\hline stolar & arcularius \\
\hline suknar & pannitonsor \\
\hline svratištar & diversitor \\
\hline šeširdžija & pileator \\
\hline štavljač kože & alutarius \\
\hline tesar & asciarius \\
\hline tkalac & textor \\
\hline tokar & torneator \\
\hline urar & horolopegus, horopeus \\
\hline užar & funifex \\
\hline voskar & ceroplasta \\
\hline zidar & murarius \\
\hline zlatar & aurifaber, auricularius \\
\hline žutomjedar & auricalcarius \\
\hline & \\
\hline
\end{tabular}


Prilog 3. Godišnja distribucija obrtničkih zanimanja u Upisniku građana između 1809. i 1814. godine $^{88}$

\begin{tabular}{|l|c|c|c|c|c|c|c|}
\hline obrtnička zanimanja & $\mathbf{1 8 0 9 .}$ & $\mathbf{1 8 1 0 .}$ & $\mathbf{1 8 1 1}$ & $\mathbf{1 8 1 2}$ & $\mathbf{1 8 1 3 .}$ & $\mathbf{1 8 1 4 .}$ & Ukupno \\
\hline bačvar & 4 & 3 & 0 & 0 & 1 & 0 & 8 \\
\hline bravar & 1 & 0 & 0 & 0 & 0 & 0 & 1 \\
\hline čarapar & 0 & 0 & 1 & 1 & 0 & 0 & 2 \\
\hline češljar & 1 & 2 & 0 & 0 & 1 & 0 & 4 \\
\hline čizmar & 2 & 5 & 7 & 2 & 1 & 1 & 18 \\
\hline dimnjačar & 1 & 0 & 0 & 0 & 0 & 0 & 1 \\
\hline duhanar & 1 & 0 & 0 & 0 & 0 & 0 & 1 \\
\hline gostioničar & 6 & 4 & 0 & 0 & 1 & 1 & 12 \\
\hline gumbar & 2 & 3 & 0 & 0 & 0 & 0 & 5 \\
\hline kazandžija & 0 & 2 & 0 & 0 & 0 & 0 & 2 \\
\hline knjigoveža & 1 & 0 & 0 & 0 & 0 & 0 & 1 \\
\hline kočijaš & 0 & 2 & 0 & 0 & 0 & 1 & 3 \\
\hline kolar & 1 & 2 & 0 & 0 & 0 & 0 & 3 \\
\hline kirurg/brijač/ranarnik & 2 & 3 & 1 & 1 & 1 & 0 & 8 \\
\hline kositrar & 0 & 0 & 1 & 0 & 0 & 0 & 1 \\
\hline kovač & 4 & 3 & 1 & 0 & 1 & 0 & 9 \\
\hline kožar & 4 & 1 & 0 & 0 & 0 & 0 & 5 \\
\hline krojač & 10 & 12 & 4 & 1 & 1 & 0 & 28 \\
\hline krznar & 6 & 5 & 0 & 2 & 0 & 0 & 13 \\
\hline limar & 2 & 0 & 0 & 0 & 0 & 0 & 2 \\
\hline lončar & 1 & 1 & 1 & 0 & 0 & 0 & 3 \\
\hline mesar & 7 & 0 & 2 & 0 & 1 & 1 & 11 \\
\hline mlinar & 7 & 3 & 0 & 0 & 0 & 0 & 10 \\
\hline mrežar & 0 & 0 & 0 & 0 & 1 & 0 & 1 \\
\hline pekar & 6 & 2 & 0 & 0 & 0 & 0 & 8 \\
\hline pivar & 1 & 2 & 0 & 0 & 0 & 0 & 3 \\
\hline pokrivar & 2 & 1 & 0 & 0 & 0 & 0 & 3 \\
\hline postolar & 0 & 3 & 0 & 1 & 1 & 0 & 8 \\
\hline puškar & 10 & 17 & 4 & 1 & 0 & 0 & 32 \\
\hline rekljar/kožuhar & 3 & 3 & 0 & 0 & 0 & 0 & 6 \\
\hline remenar & & & & & & & \\
\hline
\end{tabular}

$\overline{{ }^{88} \text { HR-DAOS-6.1.6., knj. } 460 .}$ 


\begin{tabular}{|l|c|c|c|c|c|c|c|}
\hline rešetar & 1 & 0 & 0 & 1 & 0 & 0 & 2 \\
\hline ribar & 1 & 16 & 0 & 2 & 1 & 0 & 20 \\
\hline sapunar & 3 & 0 & 0 & 0 & 0 & 0 & 3 \\
\hline sedlar & 2 & 1 & 0 & 0 & 0 & 0 & 3 \\
\hline slikar & 0 & 1 & 0 & 0 & 0 & 0 & 1 \\
\hline staklar & 3 & 1 & 0 & 0 & 0 & 1 & 5 \\
\hline stolar & 3 & 2 & 0 & 0 & 0 & 0 & 5 \\
\hline suknar & 0 & 0 & 0 & 0 & 1 & 0 & 1 \\
\hline svratištar & 19 & 12 & 2 & 7 & 8 & 0 & 48 \\
\hline šeširdžija & 2 & 2 & 0 & 0 & 2 & 1 & 7 \\
\hline štavljač kože & 0 & 3 & 0 & 1 & 0 & 0 & 4 \\
\hline tesar & 2 & 4 & 1 & 0 & 1 & 0 & 8 \\
\hline tkalac & 0 & 0 & 0 & 0 & 1 & 0 & 1 \\
\hline tokar & 1 & 0 & 0 & 0 & 0 & 0 & 1 \\
\hline urar & 0 & 1 & 0 & 0 & 1 & 0 & 2 \\
\hline užar & 3 & 1 & 0 & 0 & 0 & 0 & 4 \\
\hline voskar & 1 & 3 & 0 & 0 & 0 & 0 & 4 \\
\hline zidar & 1 & 5 & 0 & 0 & 0 & 0 & 6 \\
\hline zlatar & 1 & 1 & 0 & 0 & 1 & 1 & 4 \\
\hline žutomjedar & 0 & 1 & 0 & 0 & 0 & 0 & 1 \\
\hline Ukupno: & $\mathbf{1 3 0}$ & $\mathbf{1 3 7}$ & $\mathbf{2 5}$ & $\mathbf{2 1}$ & $\mathbf{2 6}$ & $\mathbf{7}$ & $\mathbf{3 4 6}$ \\
\hline
\end{tabular}




\section{Summary}

\section{OSIJEK CITIZENRY IN THE REGISTRY OF CITIZENS FROM THE ACQUISITION OF THE FREE AND ROYAL STATUS TO THE FIRST CENSUS OF THE NON-NOBLE POPULATION (1809-1814)}

This paper analyses the Osijek citizenry between 1809 and 1814 on the basis of data recorded in the Osijek Registry of Citizens. It provides a short description of sources that facilitate research into the citizens of Osijek; it adduces the civil rights granted by the Charter of the Free Royal City of Osijek from 1809 and the requirements for obtaining citizenship. The data analysis is based on the Registry because this source provides the highest number of individual data on each citizen. By applying statistical, comparative and descriptive methods, an endeavour is made to present the number, the religious and the "national" structure, the marital status and the scope of activities of Osijek citizens. The paper comprises the period from 1809, when Osijek acquired the free royal status, until 1814 when the Osijek non-noble population was recorded for the first time. Hence, this is the first census of commoners after Osijek was proclaimed a free royal city.

The proclamation of Osijek as a free royal city created the preconditions for the Osijek population to acquire civic status which resulted in a series of privileges for individuals, including personal freedom, inalienability of properties and non-payment of certain levies. The obtained data on the Osijek citizenry in this paper are the result of the analysis of the Registry of Citizens; the following conclusions can be drawn: in the period between 1809 and 1814, 569 persons complying with the requirements necessary for taking a civic oath were registered. The status of a citizen in terms of rank was acquired more by non-noble individuals, whereas during the period analyzed, not a single son of a citizen or emancipated serf acquired this status. The occupations of Osijek citizens were various. Artisans were the most present, the most dominant being in those trades that produced products of widespread use such as cobblers, tailors and food producers. Most of the artisans were local people. The second largest group consisted of merchants; representatives of this profession were local people and by contrast to the artisans, the majority of them were Orthodox. The Registry lists only a small number of educated people. Educated individuals working in the city government were local citizens, whereas foreigners stood out in medical professions such as pharmacy and medicine. The conclusion can be drawn that in terms of nationality a rather large number of the Osijek citizens, admitted by the city government, were foreigners; nevertheless, prevailing in the total number were Slavonians, citizens of Osijek and Croatians, i.e. representatives of the local population.

Keywords: citizenry, Registry of Citizens, Osijek, free royal city, beginning of the $19^{\text {th }}$ century

(Translated by Mica Orban Kljajić)

\section{Kontakt autorice:}

Eldina Lovaš, mag. hist.

M. Tita 148, 31307 Zmajevac

e-mail: eldina.lovas@gmail.com 